\title{
CAVE MORPHOLOGY AND CONTROLS ON SPELEOGENESIS IN QUARTZITE: THE EXAMPLE OF THE ITAMBÉ DO MATO DENTRO AREA IN SOUTHEASTERN BRAZIL
}

\section{MORFOLOGIJA IN SPELEOGENEZA JAM V KVARCITIH: PRIMER OBMOČJA ITAMBÉ DO MATO DENTRO V JOGOVZHODNI BRAZILIJI}

\author{
Fabiana P. FABRI ${ }^{1}$, Augusto S. AULER ${ }^{1 *}$, Allan S. CALUX ${ }^{2}$, Roberto CASSIMIRO ${ }^{1}$ \\ \& Cristina H. R. R. AUGUSTIN ${ }^{2}$
}

\begin{abstract}
UDC 551.435.84(81)

Fabiana P. Fabri, Augusto S. Auler, Allan S. Calux, Roberto Cassimiro \& Cristina H. R. R. Augustin: Cave morphology and controls on speleogenesis in quartzite: The example of the Itambé do Mato Dentro area in southeastern Brazil

An area of $417 \mathrm{~km}^{2}$ in southeastern Brazil was mapped in detail regarding karst features in quartzite. Landforms typically assigned to carbonate karst terrains are largely absent, except for discrete occurrences of towers and collapse dolines. Caves are the most conspicuous landform, although occurring at a lower density than in most Brazilian carbonate areas. A total of 11 caves were mapped and studied in detail. Caves tend to develop at shallow depths parallel to the slope surface, controlled by lithological facies and the hydraulic gradient. Petrographical analyses suggest that mica (sericite) lenses within the quartzite and both sericite and iron around quartz grains may favour grain disaggregation and later erosional removal in a shallow phreatic environment. Quartzite caves represent a common feature in southeastern Brazil but tend to be isolated features rather than an integrated and areally extensive hydrological system typical of many carbonate settings.

Key words: Quartzite caves, hydraulic gradient, sericite lenses.
\end{abstract}

\section{Izvleček}

UDK 551.435.84(81)

Fabiana P. Fabri, Augusto S. Auler, Allan S. Calux, Roberto Cassimiro \& Cristina H. R. R. Augustin: Morfologija in speleogeneza jam v kvarcitih: Primer območja Itambé do Mato Dentro v jogovzhodni Braziliji

$\mathrm{V}$ članku opisujemo rezultate podrobnega kartiranja krasa $\mathrm{v}$ kvarcitu na $417 \mathrm{~km}^{2}$ velikem območju v jugovzodni Braziliji. Z izjemo stolpov in udornic na območju ni površinskih kraških oblik, značilnih za karbonatni kras. Jame so najbolj značilen kraški pojav, čeprav je njihova gostota precej manjša od tiste na karbonatnem krasu. $\mathrm{Na}$ celotnem območju smo izmerili in detaljno raziskali 11 jam, ki so razvite plitvo in vzporedno s površjem. Glavna dejavnika razvoja jam sta litologija in hidravlični gradient. Petrografske analize kažejo, da je razvoj jam najbolj aktiven $\mathrm{v}$ območjih plitve freatične cone, kjer se $\mathrm{v}$ kvarcitu pojavljajo leče sljude (sericit) ter kjer sericit in železo obdajata kremenčeva zrna. $\mathrm{V}$ the območjih prihaja do razpadanja in mehanskega odnašanja zrn. V jugovzhodni Braziliji so kvarcitne jame pogost pojav, vendar so med seboj pravilpoma nepovezane, kar kaže na to, da v primerjavi s karbonatnim krasom v kvarcitu ne prihaja do razvoja velikih povezanih kraških drenažnih sistemov.

Ključne besede: Jame v kvarcitu, hidravlični gradient, sericitne leče.

\section{INTRODUCTION}

Quartzite caves are now recognised as relatively common features in many tropical areas of the world (Wray 1997a; Auler 2012; Wray 2013). Although studies have been performed since the early 1960s (White et al. 1966), systematic research on this topic is rather recent, with new information being produced every year. A significant

\footnotetext{
${ }^{1}$ Instituto do Carste, Rua Aquiles Lobo, 297, Belo Horizonte, MG, 30150-160, Brazil, aauler@gmail.com

${ }^{2}$ Departamento de Geografia, Instituto de Geociências, Universidade Federal de Minas Gerais, Avenida Antonio Carlos 6627, Belo Horizonte, MG, 31270-901, Brazil

${ }^{*}$ Corresponding author
}

Received/Prejeto: 01.12.2013 
portion of new data comes from the tepui area of southern Venezuela, where the longest and largest quartzite caves in the world have recently been discovered (Aubrecht et al. 2013; Mecchia et al. 2014).

Genesis of quartzite caves has traditionally been interpreted in terms of an early dissolutional phase (termed "arenisation") in which quartz grains boundaries are dissolved, increasing the porosity and resulting in a porous, friable rock that is subjected to later erosional removal of quartz grains (Martini 1979). The existence of dissolution processes is demonstrated by the frequent occurrence of silica speleothems, mostly coralloids (Wray 2007, 2009; Aubrecht et al. 2008), with opal being the dominant mineral. Hydrochemical studies (e.g. Piccini \& Mecchia 2009; Mecchia et al. 2014) have supported a quantitatively restricted role of dissolution, with low $\mathrm{SiO}_{2}$ content in most quartzite cave waters. However, given the long term geomorphic evolution of the area, even low levels of silica can be relevant to arenisation. The role of organic matter and microorganisms in trig- gering quartz dissolution has also been suggested (Bennet 1991; Barton et al. 2009). The relative importance of an initial dissolutional phase is subject to debate (Sauro et al. 2013; Aubrecht et al. 2013),, although there appears to be consensus that the morphology and evolution of quartzite cave systems are largely due to a later prolonged erosional phase. Indeed, some authors have recently argued that an early dissolutional phase may not be needed to explain the genesis of large quartzite cave systems (Aubrecht et al. 2011). Despite the recent progress in understanding the processes that control quartzite cave genesis, there is a lack of systematic research compared to the better studied carbonate areas.

Controls on quartzite cave development were examined through a study of a quartzite area in southeastern Brazil. Cave mapping, structural and petrographical studies were performed to investigate the cave inception processes and the relationship between the caves and their surrounding landscape.

\section{STUDY AREA}

The study area is located in the eastern state of Minas Gerais, southeastern Brazil (Fig. 1), mostly within the municipality of Itambé do Mato Dentro. This area lies in the southernmost expression of the vast Espinhaço Ridge, which extends over $1,500 \mathrm{~km}$ towards the north. Due to the need to perform detailed geomorphological work, a more restricted rectangle of $417 \mathrm{~km}^{2}$ was chosen, encompassing all significant caves.

Quartzite in the area belongs to three Units of the Sopa Brumadinho Formation of the Mid-Proterozoic Espinhaço Supergroup (Grossi Sad et al. 1997) (Fig. 2). The lower Serra do Lobo Unit is comprised of fine to coarse

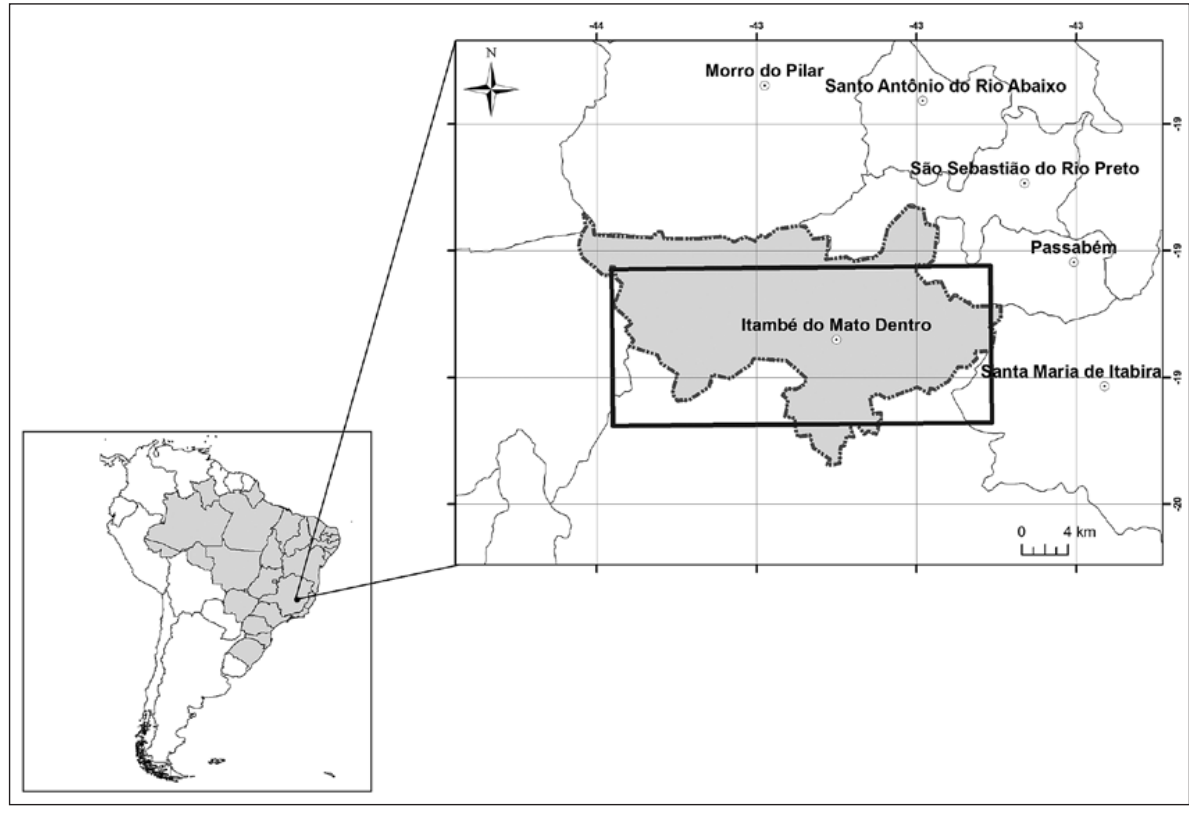




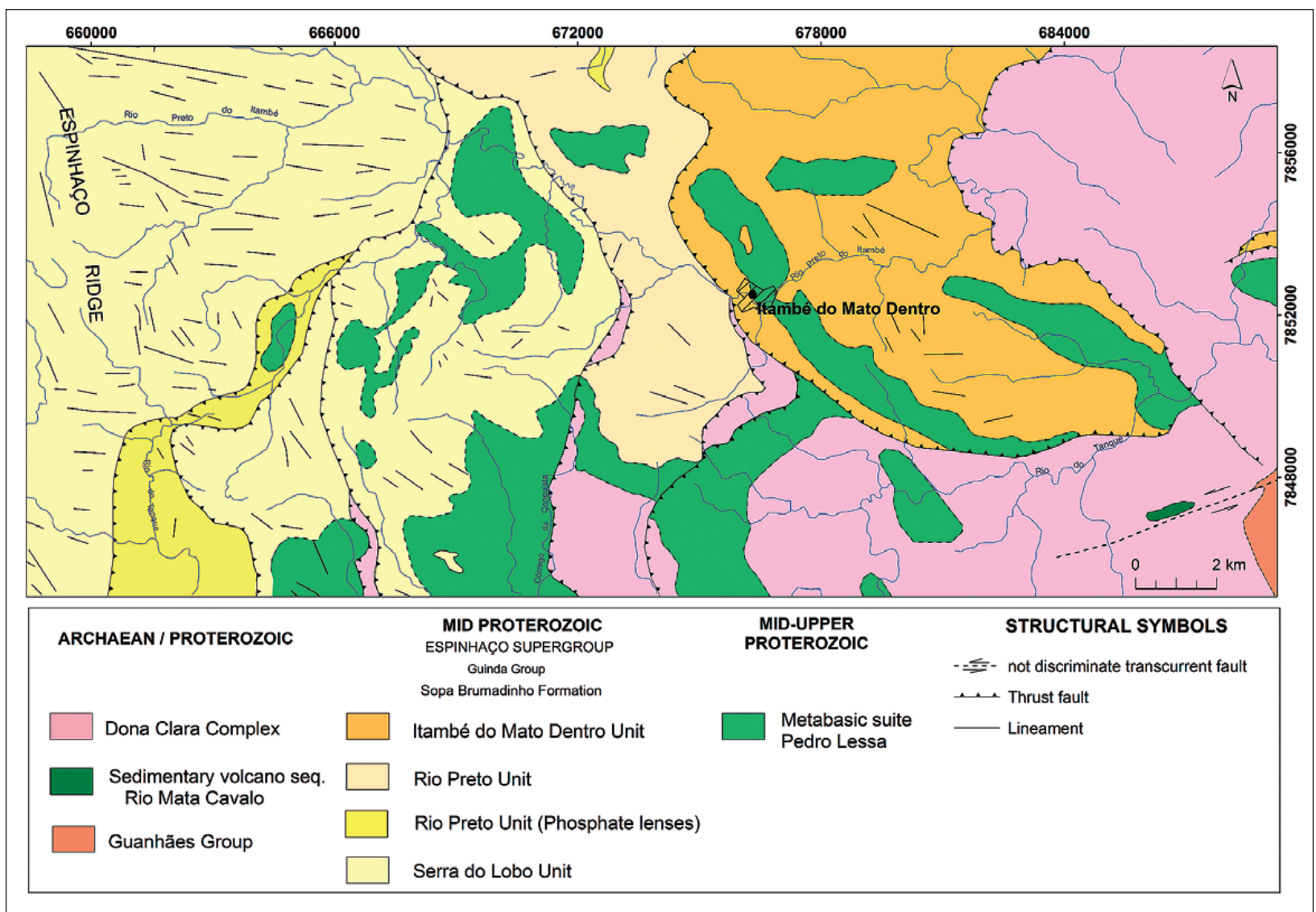

Fig. 2: Geological map of the study area (adapted from COMIG (1996)).

poorly sorted quartzite with thin laminations marked by ferruginous pellite. Hematite occurs as fine grains, although iron-rich concentrations can be observed. In addition to quartz grains, sericite can amount to up to $10 \%$ of the total volume in this unit. The Serra do Lobo Unit presents some intercalations of metaconglomerate.

The Río Preto Unit contains fine-grained quartzite with mica showing intercalations of quartz muscovite schist, haematitic quartzite, feldspar-rich quartzite and carbonate-rich quartzite. This heterogeneous unit also presents a well-marked pellite layer or ferruginous lamination. Phosphate (apatite) lenses up to $10 \mathrm{~m}$ thick have also been described.

The uppermost Itambé do Mato Dentro Unit is comprised of whitish fine-grained quartzite with hematiterich laminations. The laminations are a few millimetres thick and contain sericite and ferruginous films concentrated along the bedding planes. The quartz grains reach $99 \%$ of the total unit volume (Grossi Sad et al. 1997 ).

Quartzites are underlain by gneiss and migmatites of the Dona Rita complex. These Archaean rocks outcrop to the east of the study area. Intrusive metabasic rocks of Mid-Upper Proterozoic age occur intercalated to most geological units previously mentioned.
Quartzites present an N-S foliation, parallel to the bedding plane, defined by the orientation of micas, chlorite, amphiboles and hematite. Gentle folding and faulting (both with an N-S orientation) characterise the main structural elements of the cave-bearing rocks.

The study area of this project represents the eastern border of the mountainous quartzite domain of the Espinhaço ridge. Quartzite ridges comprise the highest zones, reaching approximately $1,700 \mathrm{~m}$ in elevation, while the lowest fluvial valleys of the Preto and Tanque rivers are located below $700 \mathrm{~m}$ in elevation. These two drainages represent the local base level, containing within their catchment area all caves identified during this study (Fig. 3). The annual rainfall is between 1,300$1,600 \mathrm{~mm}$. The well-defined dry season is between April and October. The wetter months are December to March and are responsible for over $80 \%$ of the yearly precipitation. The average annual temperature is approximately $21{ }^{\circ} \mathrm{C}$. The present vegetation is comprised of savannah, grasslands, and the remains of rainforest, with an increasing degree of modification due to agriculture. 


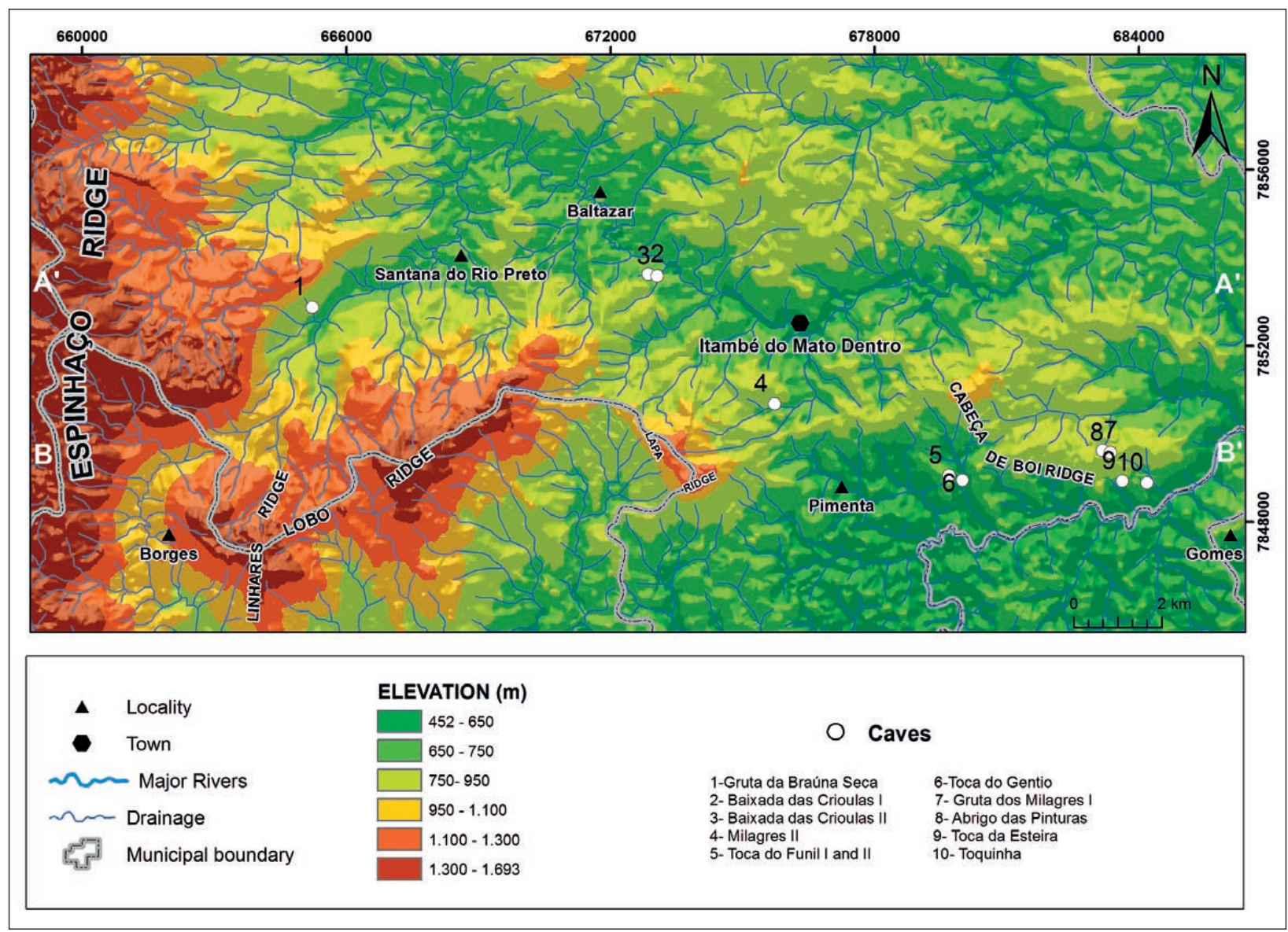

Fig. 3: Hypsometric map, fluvial network, location of caves and regional profiles.

\section{METHODS}

A previous speleological study (Cruz et al. 1999) indicated the presence of quartzite caves in the Cabeça de Boi Ridge. Further prospective work detected additional quartzite caves, identified mostly through information from local farmers. The study area was thus defined based on the location of caves and the presence of major ridges (Cabeça de Boi, Lobo, Linhares, Lapa and Espinhaço ridges).

The caves were mapped using conventional cave survey equipment (Suunto compasses and clinometers) and Leica Disto laser tapes. Survey grades reached BCRA grade $4 \mathrm{C}$. The morphology of each cave was examined through cave maps and measurements at individual cave passages. Rock samples were collected at selected locations and analysed through thin sections, mineralogy being determined through a XPERT-PRO X-ray diffractometer. Structural data were measured at cave passages using a Brunton Geo compass and processed through StereoNet 2.10 software.

Five regional topographic profiles were produced, together with local profiles along the main axis of cave development. These profiles were produced with the aid of Global Mapper 10.02 software, complemented with field measurements. Regional profiles were used to obtain the regional relief gradient. Map analyses of those slopes containing caves were used to infer the local relief gradient through the relation:

[(Amax - Amin) / D] x 100 where:

Amax - Maximum altitude of the profile

Amin - Minimum altitude of the profile

D - Distance between Amax and Amin

The cave drainage gradients were inferred through profiles of stream passages. The remaining quantitative morphometric cave data were obtained through measurements on cave maps using AutoCAD software. 


\section{KARST GEOMORPHOLOGY}

Karst-like surface forms in the study area are largely absent, as observed in many quartzite terrains in Brazil. A few closed depressions were identified, some associated with cave collapse or elongated parallel to joints (Fig. 4a). Scarp dissection leads to individualisation of towers (Fig. 4b) that resemble limestone karst towers but do not necessarily imply dissolutional processes. Smaller features such as honeycomb weathering (Mustoe 1982) also occur.

\section{UNDERGROUND LANDFORMS}

A total of 11 caves were identified and studied. Their location is presented in Fig. 3. Tab. 1 presents general speleometric data. Most caves are rather small, with the notable exception of the Baixada das Crioulas I and II caves, which represented a single major ( $>1 \mathrm{~km}$ long) cave separated by a short breakdown canyon. These fragmentary caves (approximately $40 \%$ of the caves are less than $100 \mathrm{~m}$ long) pose difficulties to the interpretation

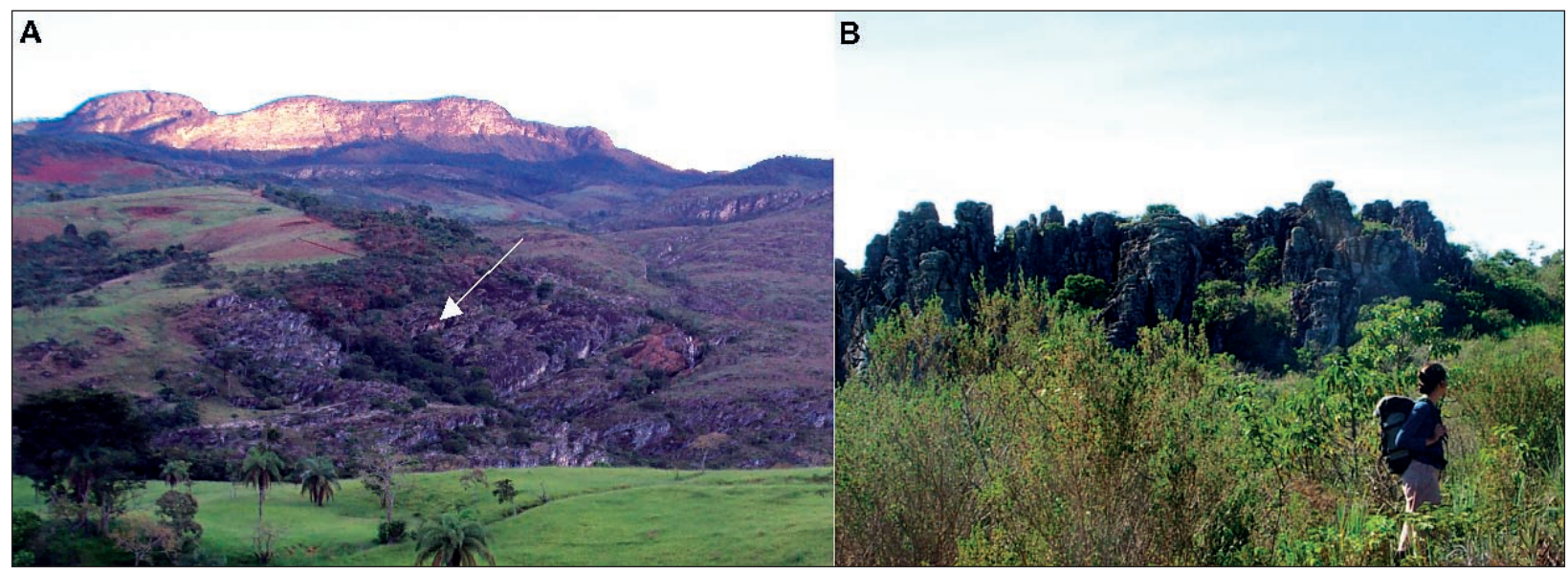

Fig. 4: A-Regional view of the study area showing a large closed depression (see arrow). B-Karst-like residual towers.

Tab. 1: Speleometric data for the studied caves. Cave density relates to the ratio between the cave area and the smallest rectangle that contains the entire cave. Sinuosity is represented by the ratio between the fluvial channel meandering length and the straight line distance between ends. * Measurement not possible due to cave pattern.

\begin{tabular}{l|c|c|c|c|c|c|c|c|c|c}
\hline Caves & $\begin{array}{c}\text { UTM } \\
\text { Coordinates }\end{array}$ & $\mathrm{N}$ & $\mathrm{S}$ & $\begin{array}{c}\text { Length } \\
(\mathrm{m})\end{array}$ & $\begin{array}{c}\text { Depth } \\
(\mathrm{m})\end{array}$ & $\begin{array}{c}\text { Area } \\
\left(\mathrm{m}^{2}\right)\end{array}$ & $\begin{array}{c}\text { Volume } \\
\left(\mathrm{m}^{3}\right)\end{array}$ & $\begin{array}{c}\text { Density } \\
\text { Maximum distance }\end{array}$ & $\begin{array}{c}\text { Sinuosity } \\
\text { between extremes }\end{array}$ & $\begin{array}{c}\text { Number of } \\
\text { entrances }\end{array}$ \\
\hline $\begin{array}{l}\text { Abrigo das } \\
\text { Pinturas }\end{array}$ & 7849576 & 683355 & 65 & 8 & 518 & 1677 & 0.156 & 65 & & $*$ \\
\hline $\begin{array}{l}\text { Baixada das } \\
\text { Crioulas I }\end{array}$ & 7853631 & 672862 & 1074 & 75 & 6659.6 & 27572 & 0.05 & 517.13 & 1.12 & 1 \\
\hline $\begin{array}{l}\text { Baixada das } \\
\text { Crioulas II }\end{array}$ & 7853583 & 673059 & 205 & 13.5 & 1776.7 & 18510 & 0.19 & 163.77 & 1.04 & 3 \\
\hline Braúna Seca & 7852893 & 665102 & 37 & 7 & 193 & 611 & 0.386 & 22.5 & 1.03 & 2 \\
\hline Esteira & 7848930 & 683629 & 96 & 28 & 335 & 1461 & 0.142 & 68.55 & 1.01 & 4 \\
\hline Funil I & 7849054 & 679690 & 21 & 4 & 141 & 595 & 1,433 & 21 & 1.01 & 1 \\
\hline Funil II & 7849054 & 679690 & 106 & 29 & 534 & 618 & 0.0945 & 105.22 & 1.01 & 1 \\
\hline Gentio & 7848947 & 679991 & 14 & 2 & 53 & 166 & 0.571 & 13.68 & 1.03 & 1 \\
\hline Milagres I & 7849656 & 683048 & 225 & 14 & 1100.3 & 3344 & 0.0586 & 125.72 & & 3 \\
\hline Milagres II & 7850686 & 675724 & 149 & 17 & 806 & 1136 & 0.113 & 143.62 & 1.01 & 2 \\
\hline Toquinha & 7848930 & 683629 & 6 & 1.5 & 9.3 & 4.36 & 0.153 & 6 & 1 & 1 \\
\hline
\end{tabular}


Tab. 2: Regional, local and stream passage gradients for the studied caves.

\begin{tabular}{|c|c|c|c|c|c|}
\hline Caves & Lithology & $\begin{array}{l}\text { Regional relief } \\
\text { gradient (\%) }\end{array}$ & $\begin{array}{l}\text { Local relief } \\
\text { gradient (\%) }\end{array}$ & $\begin{array}{l}\text { Drainage network } \\
\text { gradient(\%) }\end{array}$ & $\begin{array}{l}\text { Cave length } \\
\text { (m) }\end{array}$ \\
\hline $\begin{array}{l}\text { Abrigo das } \\
\text { Pinturas }\end{array}$ & $\begin{array}{l}\text { Itambé do Mato Dentro Unit. Medium to } \\
\text { fine granulometry. }\end{array}$ & $3-8$ & 10.42 & 5.78 & 65 \\
\hline $\begin{array}{l}\text { Baixada das } \\
\text { Crioulas I }\end{array}$ & $\begin{array}{l}\text { Serra do Lobo e Río Preto Units. Medium } \\
\text { to fine granulometry, with sericite films. }\end{array}$ & $8-20$ & 10.65 & 10.02 & 1074 \\
\hline $\begin{array}{l}\text { Baixada das } \\
\text { Crioulas II }\end{array}$ & $\begin{array}{l}\text { Rio Preto Unit. Medium to fine } \\
\text { granulometry, with sericite films. }\end{array}$ & $8-20$ & 10.65 & 10.02 & 205 \\
\hline Braúna Seca & $\begin{array}{l}\text { Rio Peto Unit (phosphate lenses). Medium } \\
\text { to fine granulometry.. }\end{array}$ & $8-20$ & 42.96 & 30.02 & 37 \\
\hline Esteira & $\begin{array}{l}\text { Itambé do Mato Dentro Unit. Medium to } \\
\text { fine granulometry, with sericite films. }\end{array}$ & $20-45$ & 27.4 & 17.78 & 96 \\
\hline Funil I & $\begin{array}{l}\text { Itambé do Mato Dentro Unit. Medium to } \\
\text { fine granulometry, with sericite films. }\end{array}$ & $8-20$ & 14.32 & 22.9 & 21 \\
\hline Funil II & $\begin{array}{l}\text { Itambé do Mato Dentro Unit. Medium to } \\
\text { fine granulometry. }\end{array}$ & $8-20$ & 14.32 & 22.9 & 106 \\
\hline Gentio & $\begin{array}{l}\text { Itambé do Mato Dentro Unit. Medium to } \\
\text { fine granulometry. }\end{array}$ & $8-20$ & 14.32 & 22.9 & 14 \\
\hline Milagres I & $\begin{array}{l}\text { Itambé do Mato Dentro Unit. Medium to } \\
\text { fine granulometry, with sericite films. }\end{array}$ & $3-8$ & 8.28 & 5.78 & 225 \\
\hline Milagres II & $\begin{array}{l}\text { Itambé do Mato Dentro Unit. Medium to } \\
\text { fine granulometry. }\end{array}$ & $8-20$ & 17.78 & 9.14 & 149 \\
\hline Toquinha & $\begin{array}{l}\text { Itambé do Mato Dentro Unit. Medium to } \\
\text { fine granulometry. }\end{array}$ & $8-20$ & 31.76 & 23.56 & 6 \\
\hline
\end{tabular}

of large scale morphology and genesis because they are not long enough to allow for a full display of the cave pattern.

Most caves occur as isolated landforms, resulting in a density of 0.026 caves $/ \mathrm{km}^{2}$. Caves develop mostly in the less resistant quartzite of the Río Preto and Itambé do Mato Dentro Units. No correlation was found between slope gradient and cave development, and no caves were located in areas of very high gradient; the majority of caves occur in slopes of $8-20 \%$ (Tab. 2 and Fig. 5).

The longer caves tend to contain a perennial stream, displaying a linear plan pattern with few or no tributaries (Fig. 6). Values for sinuosity are close to 1 (Tab. 1). The major caves tend to follow the slope gradient, being characterised by an inclined passage that frequently represents a link between upper (inlet) and lower (outlet) entrances. The majority of the caves possess less than 3 entrances, while most of the shorter ones displays a single entrance. An important exception is represented by Baixada das Crioulas I and II caves because they contain numerous entrances (Fig. 6) associated with inlets at the western/northwestern limit, possibly associated with the presence of a nearby scarp that favoured breakdown and surface water input to the caves.

Cave walls exhibit friable quartzite that precludes preservation of possible original hydrodynamic forms.
Irregular pillars occur in many caves. Cross sections are, on average, at most a few meters in terms of height and width. However, sections show considerable variation. Caves that contain streams (Baixada das Crioulas, Funil, Milagres, Esteira) show passages with a width/height ratio of approximately 2 (Fig. 7) and are square or lensshaped. Keyhole passages have also been identified in the area. Joint-controlled rift passages occur in selected caves (Milagres).

The relatively homogeneous character of the geology surrounding the caves, comprised of mostly quartzite, results in an equally monotonous sedimentation inside caves. Sand residues are by far the commonest sediment, both of autogenic (crumbling breakdown of friable walls/ ceiling) and allogenic sources (Fig. 8). Fine-grained clay and silt are observed at a few sites. Rare deposits of poorly sorted coarser and sometimes brecciated sediments have been recorded in some caves (Baixada das Crioulas, Funil II), usually related to paleo-fluvial terraces (Fig. 9).

Chemical sedimentation (speleothems) is limited mostly to coralloids and small stalactites. X-ray diffractometry has shown that speleothems are composed of quartz and opal-A, similar to the findings from sandstone and quartzite caves elsewhere (Wray 1997b; 1999; 2013; Wiegand et al. 2004; Aubrecht et al. 2008). Coralloids are not commonly associated to joints; this finding 

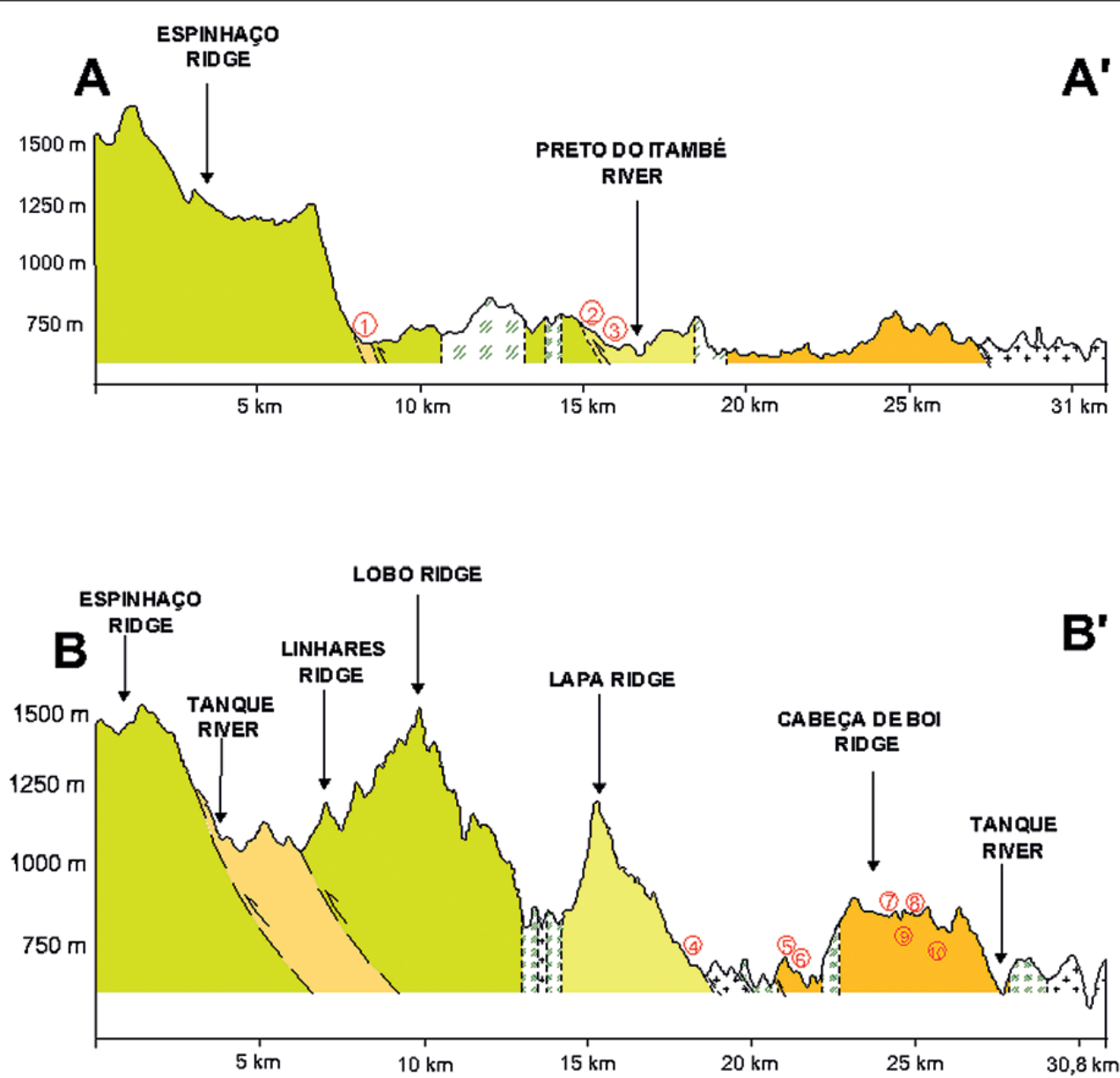

\section{Legend}

Caves

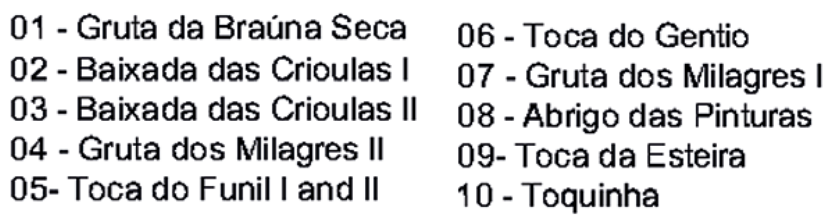

05- Toca do Funil I and II 10 - Toquinha

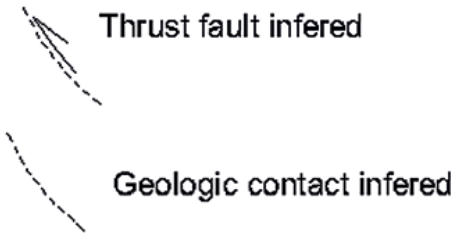

\section{ESPINHAÇO SUPERGROUP}

Serra do Lobo Unit

Rio Preto Unit

Rio Preto Unit (phophate lenses)

Itambé do

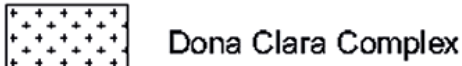
Mato Dentro Unit

Fig. 5: Selected regional profiles showing geology and cave locations. Profile locations in Fig. 3. 


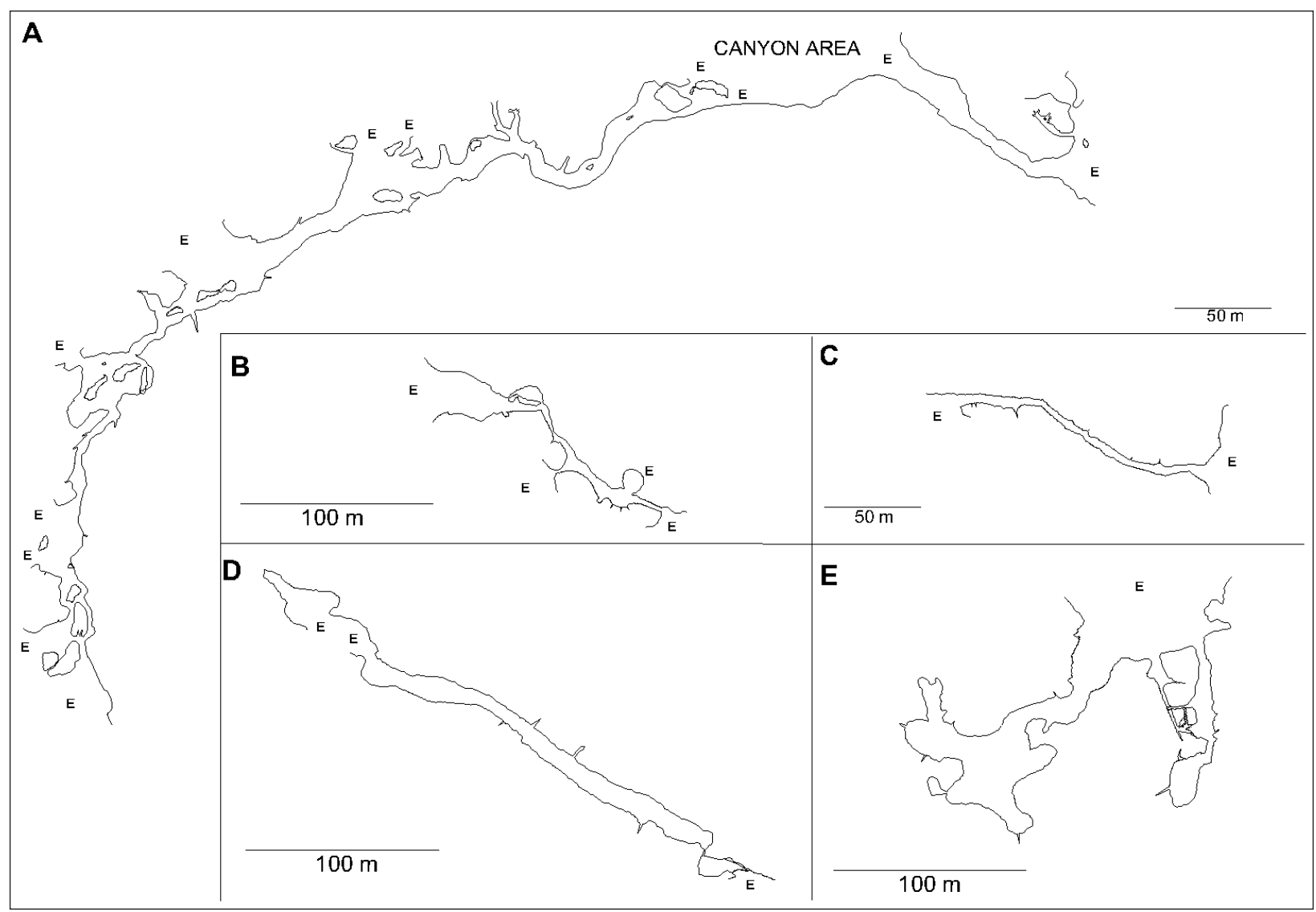

Fig. 6: Cave pattern in plan view of some of the studied caves. A - Baixada das Crioulas I and II caves. B - Esteira cave. C - Milagres II cave. D - Funil I cave. E - Milagres I cave. E - (Entrance)

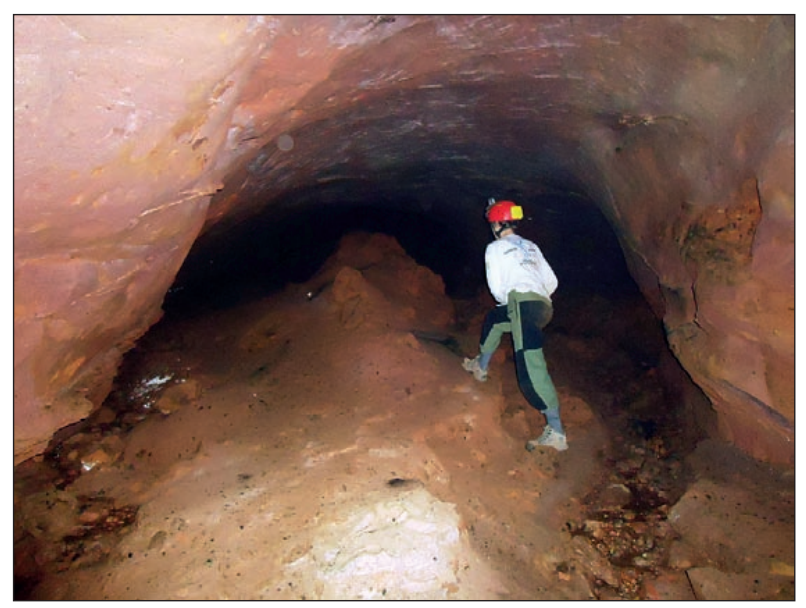

Fig. 7: Lens-shaped passage with small streams at the wall/floor contact at Funil II cave. Fine-grained sedimentation at the centre of the passage.

indicates water input through rock porosity, as suggested by Wray (1999) in Australian caves and Mecchia et al. (2014) in the Venezuelan tepui caves. Thin section of stalactites allows the observation of an irregular display

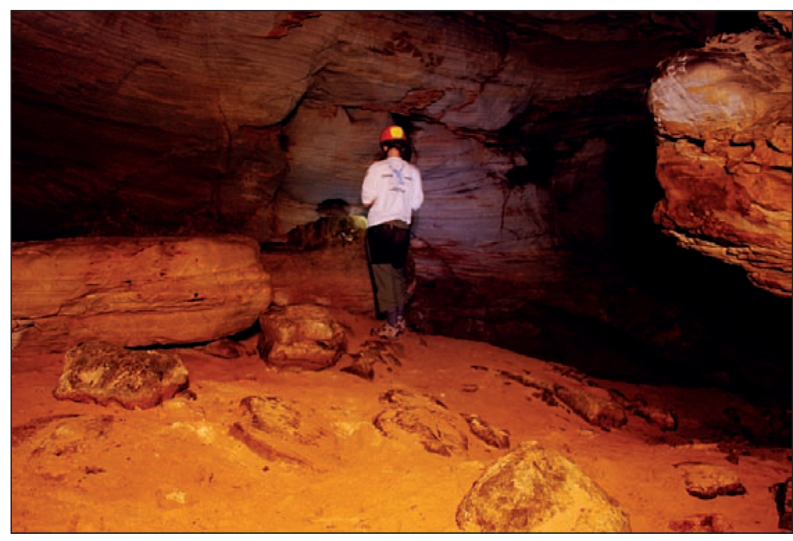

Fig. 8: Sand residue and quartzite breakdown at Milagres I cave.

of opal layers parallel to a central axis. No evidence of an internal channel has been found, as noted by Wray (1997b). Another type of speleothem is represented by colloidal dark reddish brown flowstone, with crenulated surfaces that resemble millimetre wide rimstone dams. This type of deposit has been previously interpreted by Corrêa Neto et al. (1997) as expansive clays with allo- 


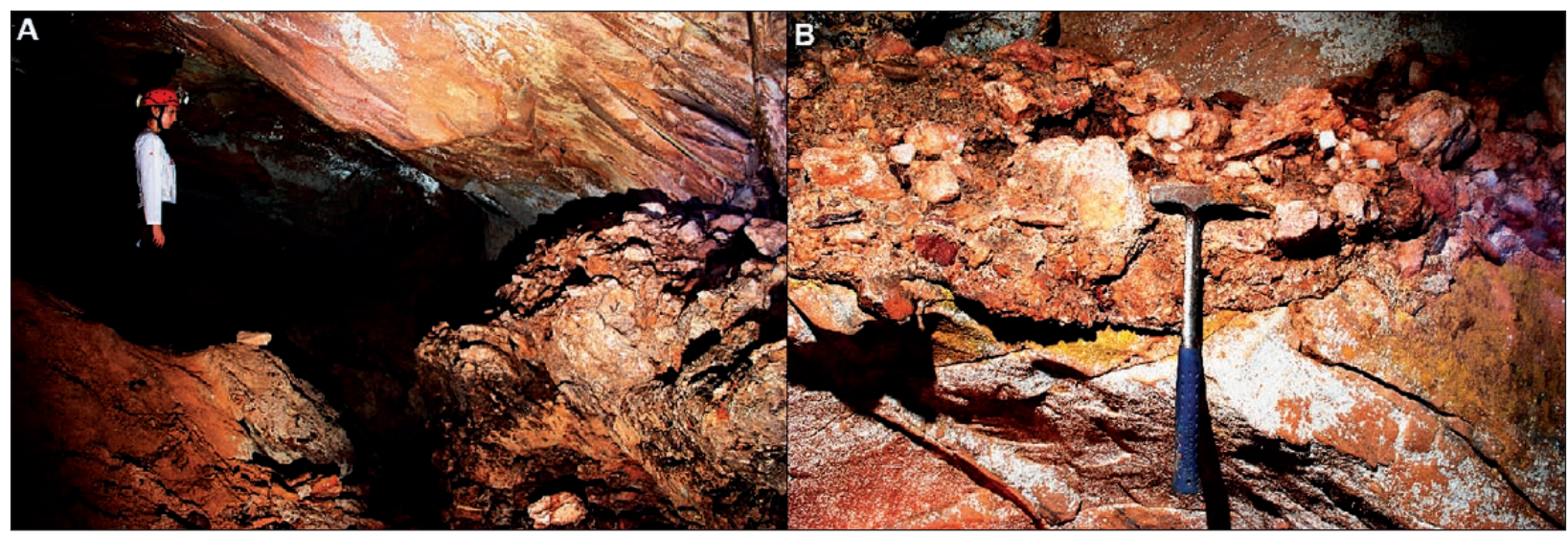

Fig. 9: Alluvial coarse grained terrace at Baixada das Crioulas II cave. A-General view. B-Close-up view.

phane and amorphous bauxite, derived from the weathering of aluminium silicates. X-ray diffractometry analy- ses indicate that quartz intermixed with clay material of undetermined mineralogy.

\section{CONTROLS ON CAVE GENESIS}

Approximately 800 measurements of joints, bedding and foliation planes were performed inside caves (Fig. 10). The most prominent joint direction is N0-20E, not closely correlated to cave passage orientation, which displays a more prominent direction at N80-90E. When passage type is taken into account, stream caves show limited

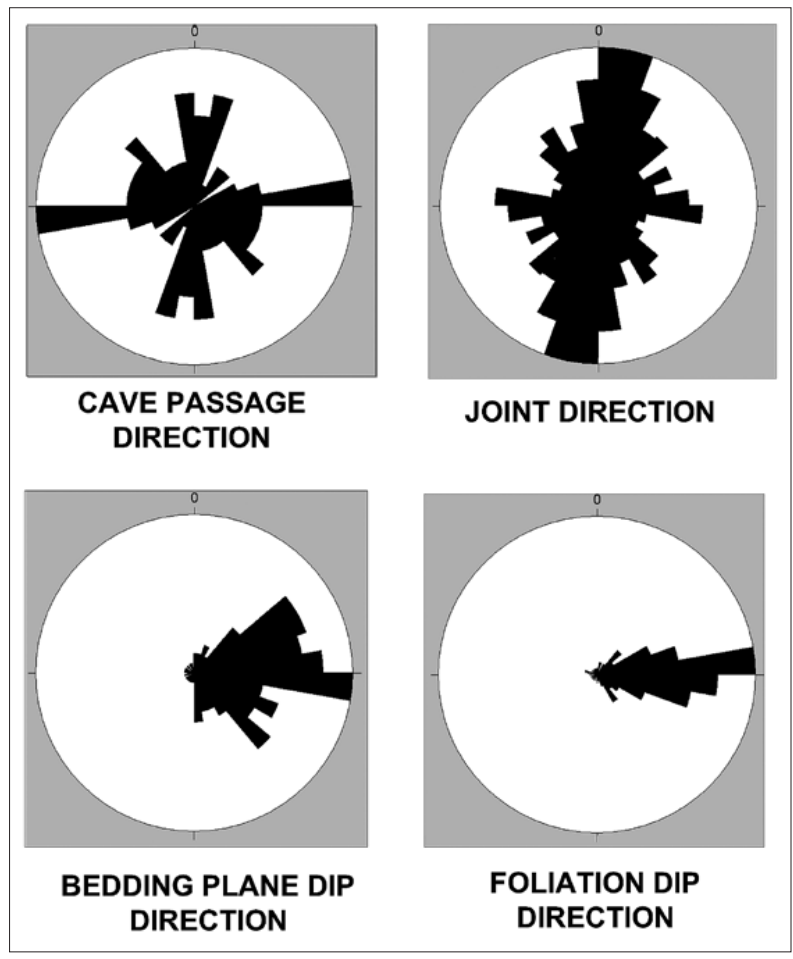

control by joints, joint direction correlation being found mostly in rift passages in dry caves, such as Milagres cave. Passage direction appears to be controlled by the dip direction of both bedding plane and foliation, showing these structural elements may be of importance in determining the position of passage initiation.

Baixada das Crioulas I and II caves exhibit a curious curvilinear pattern that is not found elsewhere in the area (Fig. 6). The cave passage closely follows a surface valley, suggesting a similar control for both surface and underground water flow.

The relationship between caves and the hydraulic gradient was analysed. Cave profiles, as previously mentioned, closely mirror the slope gradients (Fig. 11). Tab. 2 shows slope gradients for the caves, both in a regional and local (in the scale of the cave) context. There is no clear correlation between slope gradient and cave length, although all caves (with the exception of the horizontal Milagres I cave) develop within gradients $>10^{\circ}$. Furthermore, the caves appear to be aligned with the steepest slope gradient. Cave development appears to follow a favourable horizon whenever quartzite dip direction is aligned with the hydraulic gradient. Most caves develop in such conditions, being less conspicuous in horizontal rock/relief settings.

Fig. 10: Stereonet directions of cave passages, fractures, bedding plane and foliation for measurements in all caves. 


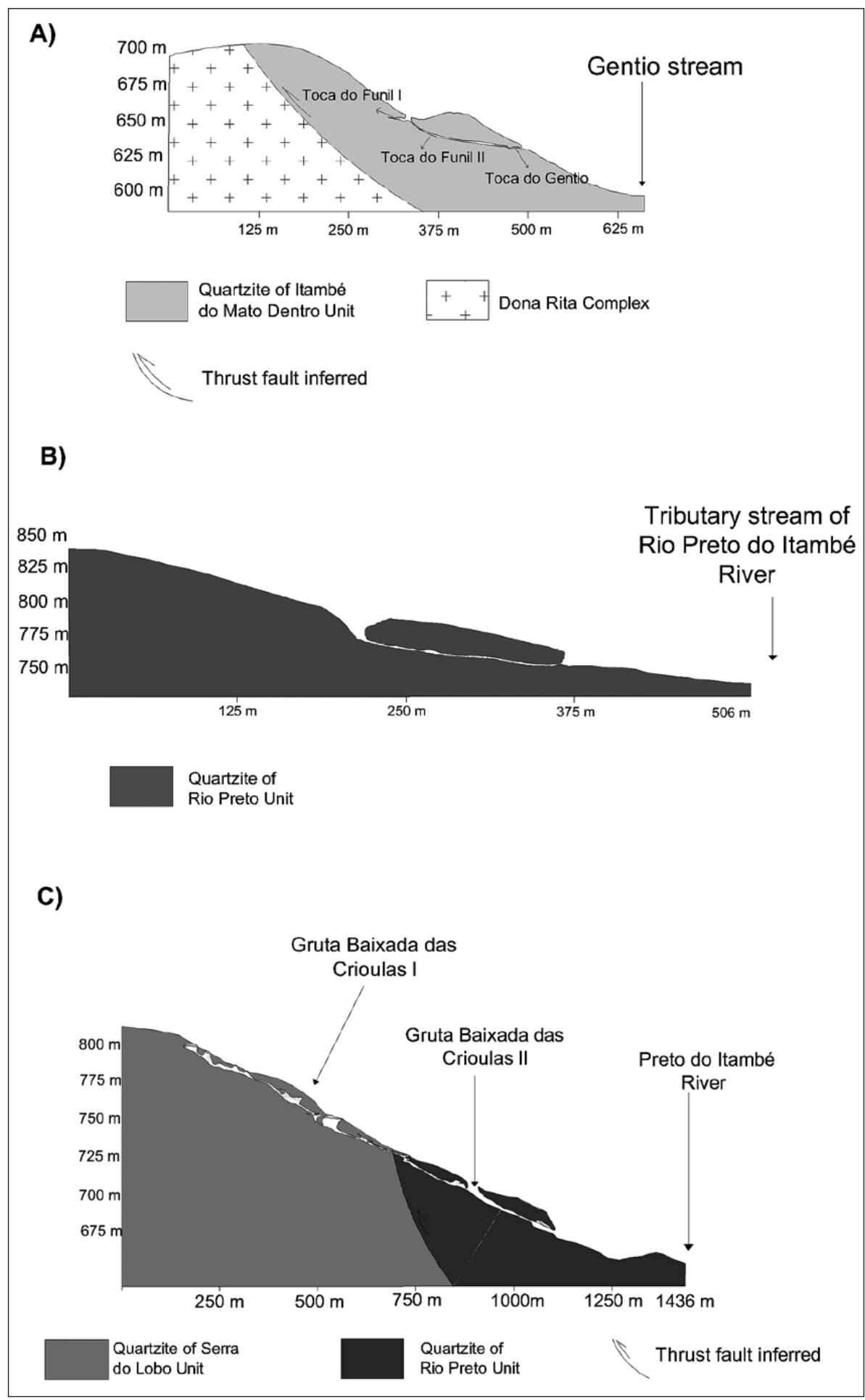

Fig. 11: Relationship between cave and slope profiles, showing that caves tend to develop close to the surface. A- Funil I, II and Gentio caves. B- Milagres II cave. C- Baixada das Crioulas I and II caves.

Quartzite samples taken at Funil II, Milagres I and II and Baixada das Crioulas I caves were subject to petrographical and geochemical analyses. They are comprised of fine to medium-grained quartzite with a high (>85\%) content of quartz but with significant amounts
(5-10\%) of sericite. Iron oxides/hydroxides also occur associated with sericite. Sericite tends to occur as films associated with the foliation (Fig. 12) but also enveloping quartz grains. Sampling in both ceiling and pillars demonstrated that the residual pillars are characterised 

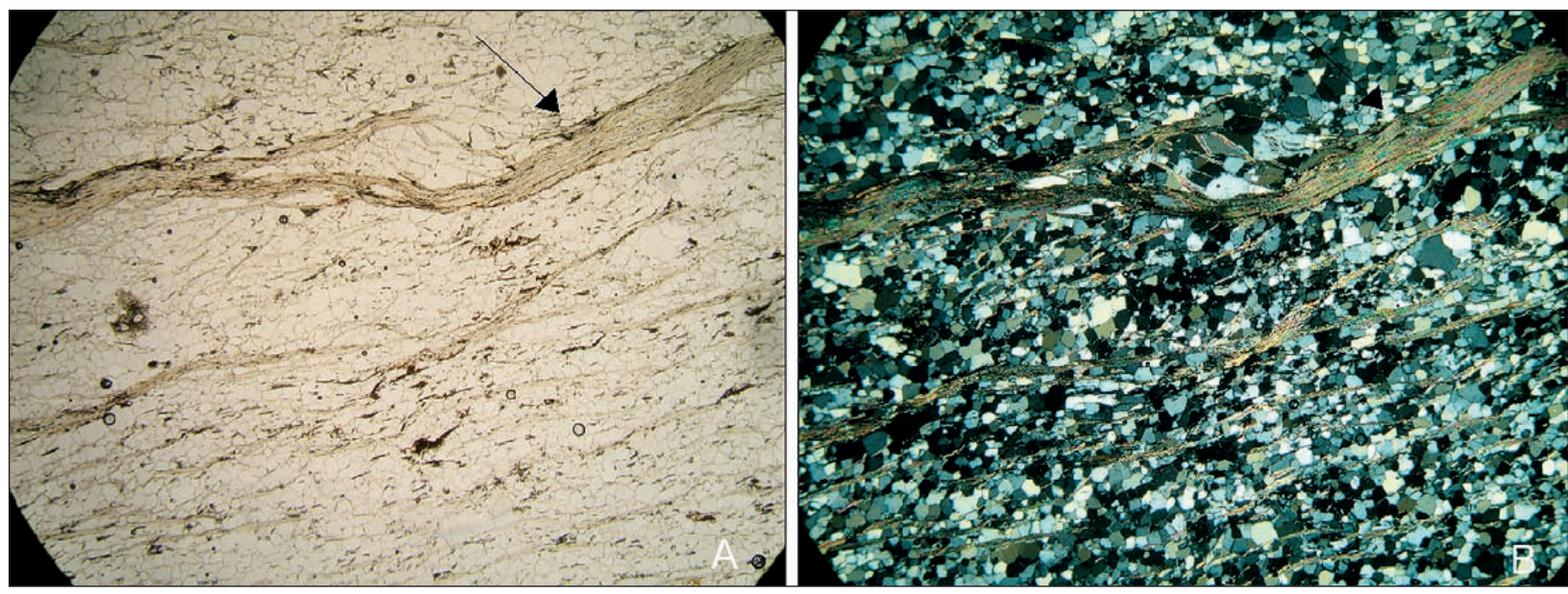

Fig. 12: Sericite (see arrow) occur as continuous lenses that determines the rock foliation. Photomicrography from a sample from Baixada das Crioulas I cave.

by a lower (5-10\%) amount of sericite, while higher amounts (15-20\%) were recorded in the ceiling. Lower levels of sericite may thus result in more chemically resistant rock, suggesting that sericite/iron content may play a major role in cave initiation in the area. One of the largest volumes among the studied caves is related to a mica-rich zone where the "big chamber" of Milagres I cave develops.

\section{DISCUSSION}

Caves in the Itambé do Mato Dentro area share many characteristics observed in quartzite caves elsewhere in Brazil (Corrêa Neto 2000; Wiegand et al. 2004; Auler 2012). Genesis of quartzite caves is traditionally attributed to dissolution along the boundaries of quartz grains, allowing for later erosional removal of constituents (Martini 1979; Wray 1997a, 2013). The role of dissolution in quartzite cave development is usually considered to be restricted to the initial phases of speleogenesis, being considerably small when compared to the later erosional phases. Some authors have even claimed that a dissolutional phase is not required to explain some of the largest and longest quartzite caves in the world (Aubrecht et al. 2011). In the study area, however, there is clear evidence of chemical alteration of an original, very hard and crystalline rock as observed in outcrops, resulting in a friable water-soaked rock that is easily removed under the existing hydraulic gradient.

Studies performed in Brazilian quartzite caves have stressed the importance of more readily weathered constituents in providing the initial route for ground water flow. These more favourable horizons (termed "inception horizons" by Lowe (1992)) can represent loci for the initial development of caves. Corrêa Neto (2000) first suggested that the alteration of micas, feldspars and clay minerals may be an important mechanism in cave genesis at Ibitipoca ridge, southeastern Brazil. Melo \& Giannini (2007) argue that kaolinite dissolution is the main trigger in the formation of karst landforms in the Furnas Formation of southern Brazil. In the Venezuelan tepuis, lenses of iron hydroxide or silt layers have been considered as possible inception horizons (Sauro 2014).

Bedding planes and foliation are the most common controlling structures on passage orientation in the study area. The existence of sericite layers precisely along the same horizons, as shown by petrographical analysis, may present a favourable condition for cave development, especially when the dip is in accordance with the hydraulic gradient. Furthermore, both sericite and iron oxides also occur alongside quartz grains. The weathering of mica releases both $\mathrm{K}$ and $\mathrm{Mg}$, which may accelerate the dissolution of amorphous silica and $\mathrm{SiO}_{2}$ (Icenhower \& Dove 2000). Micas and clay minerals can also be important players in the dissolution of quartz in sandstone (Bjørkum et al. 1996; Meyer et al. 2006). Laterisation processes due to alteration of micas, feldspar and clay minerals may account for considerable generation of porosity (Corrêa Neto 2000; Aubrecht et al. 2011) and favour arenisation along or around specific beds (Mecchia et al. 2014). Iron can also be significantly mobilised through various pro- 
cesses involving microbiological agents, contributing to porosity generation (Chalcraft \& Pye 1984; Striebel \& Schaferjohann 1997; Barton 2013; Sauro 2014).

The studied caves develop at a shallow depth (less than $50 \mathrm{~m}$ below the surface) and show a general concordance with the slope gradient. Although no direct relationship between cave length and slope gradient was recorded in the area, optimal conditions for quartz removal appear to occur when both hydraulic gradient and bedding/foliation planes (containing sericite/iron) are aligned.

\section{CONCLUSIONS}

A study of 11 quartzite caves in southeastern Brazil has shown that caves are not a conspicuous geomorphological landform, but occur as isolated shallow features with a density of 0.026 caves $/ \mathrm{km}^{2}$, lower than in most carbonate karst areas in Brazil. Regional and local profiles show that caves develop parallel to the surface terrain and are not linked to deep groundwater flow paths. Bedding and foliation planes are the controlling structures in guiding the initial phase of speleogenesis. Thin sections demon- strate that sericite layers occur aligned with the bedding planes and iron oxides/hydroxides are common around quartz grains. Weathering processes associated with both iron and sericite tend to free quartz grains (arenisation), allowing for the erosional removal of quartz, as demonstrated in other quartzite areas of the world. Although quantitatively small, chemical alteration of phyllosilicates is of paramount importance in defining the early circulation paths in an essentially shallow phreatic setting.

\section{ACKNOWLEDGMENTS}

Financial support was provided by FAPEMIG (grant CRA APQ 01652-09). We acknowledge the contribution of Instituto do Carste in helping organise cave surveys and data collection in the field. Régis de Paula Reis,
Tatiana Souza and the local guide Zequita helped with field work. Francesco Sauro and an anonymous reviewer provided insightful suggestions that helped improve the manuscript.

\section{REFERENCES}

Aubrecht, R., Lánczos, T., Smida, B., Brewer-Carias, C., Mayoral, F., Schlogl, J., Audy, M., Vlcek, L., Kovacik, L. \& M. Gregor, 2008: Venezuelan sandstone caves: a new view on their genesis, hydrogeology and speleothems.- Geol. Croat, 61, 345-362.

Aubrecht, R., Lanczos, T., Gregor, M., Schlogl, J., Smida, B., Liscak, P., Brewer-Carias, C. \& L. Vlcek, 2011: Sandstone caves on Venezuelan tepuis: Return to pseudokarst?- Geomorphology, 132, 351-365.

Aubrecht, R., Lanczos, T., Gregor, M., Schlogl, J., Smida, B., Liscak, P., Brewer-Carias, C. \& L. Vlcek, 2013: Reply to the comment on "Sandstone caves on Venezuelan tepuis: Return to pseudokarst?- Geomorphology, 197, 197-203.
Auler, A.S., 2012: Quartzite caves of South America.- In: White, W.B. \& D.C. Culver. (eds.) Encyclopedia of Caves. Academic Press, pp. 635-639, Chenai.

Bennet, P.C., 1991: Quartz dissolution in organic rich aqueous systems.- Geochimica et Cosmochimica Acta, 55, 1781-1797.

Barton, H.A., 2013. Biospeleogenesis.- In: Frumkin, A. (ed.) Treatise on Geomorphology Academic Press, 6, pp. 38-56, San Diego.

Barton, H., Suarez, P., Muench, B., Giarrizzo, J., Broering, M., Banks, E. \& K. Venkateswaran, 2009: The alkali speleogenesis of Roraima Sur Cave, Venezuela.- In: Proceedings $15^{\text {th }}$ International Congress of Speleology, 19 $9^{\text {th }}-26^{\text {th }}$ June 2009, Kerrville. National Speleological Society, 802-807. 
Bjørkum, P.A., 1996: How important is pressure in causing dissolution of quartz in sandstones?- Journal of Sedimentary Research, 66, 147-154.

Chalcraft, D. \& K. Pye, 1984: Humid tropical weathering of quartzite in southeastern Venezuela.- Zeitschrift fur Geomorphologie, 28, 321-332.

COMIG., 1996: Geological map of Conceição do Mato Dentro sheet.- Projeto Espinhaço 1:100.000.

Corrêa Neto, A.V. \& G. Dutra, 1997: A provincia espeleológica quartzítica Andrelândia, sudeste de Minas Gerais.- In: Proceedings XXIV Brazilian Congress of Speleology, 57-64.

Corrêa Neto, A.V., 2000: Speleogenesis in quartzites in southeastern Minas Gerais, Brazil.- In: Klimchouk, A. et al. (ed.). Speleogenesis. Evolution of Karst Aquifers. National Speleological Society, pp. 452-457, Huntsville.

Cruz, L.V., Pereira, M., Lopes, M.V.C.O. \& R.C. Mourão, 1999: Avaliação espeleológica da Serra Cabeça de Boi, Fazenda Ponte - Itambé do Mato Dentro MG.- Proceedings XXV Brazilian Congress of Speleo$\log y, 27-39$.

Grossi Sad, J.H., Mourão, M.A.A., Guimarães, M.L.V. \& L.G. Knauer, 1997: Geologia da Folha Conceição do Mato Dentro, Minas Gerais. Projeto Espinhaço: CDRom.

Icenhower, J. \& P. Dove, 2000: The dissolution kinetics of amorphous silica into sodium chloride solutions: Effects of temperature and ionic strength.- Geochimica et Cosmochimica Acta, 64, 4193-4203.

Lowe, D.J., 1992: The origin of limestone caverns: An inception horizon hypothesis.- $\mathrm{PhD}$ thesis, Manchester Metropolitan University, 512pp.

Martini, J., 1979: Karst in the Black Reef Quartzite near Kaapsehoop, Transvaal.- Annals Geological Survey of South Africa, 13, 115-128.

Mecchia, M. \& L. Piccini, 1999: Hydrogeology and $\mathrm{SiO}_{2}$ geochemistry of the Aonda Cave System, AyuanTepui, Bolivar, Venezuela.- Boletin de la Sociedad Venezolana de Espeleologia, 33, 1-11.

Mecchia, M., Sauro, F., Piccini, L., De Waele, J., Sanna, L., Tisato, N., Lira, J. \& F. Vergara, 2014: Geochemistry of surface and subsurface waters in quartz-sandstones: significance for the geomorphic evolution of tepui table mountains (Gran Sabana, Venezuela).Journal of Hydrology, 511, 117-138.

Melo, M.S. \& P.C.F. Giannini, 2007: Sandstone dissolution landforms in the Furnas Formation, Southern Brazil.- Earth Surface Processes and Landforms, 32, 2149-2164.
Meyer, E.E., Greene, G.W., Alcantar, N.A., Israelachvili, J.N. \& J.R. Boles, 2006: Experimental investigation of the dissolution of quartz by a muscovite mica surface: Implications for pressure solution.- Journal of Geophysical Research, 111, 1-4.

Mustoe, G.E., 1982: The origin of honeycomb weathering.- Geological Society of America Bulletin, 93, 108-115.

Piccini, L. \& M. Mecchia, 2009: Solution weathering rate and origin of karst landforms and caves in the quartzite of Ayuan-tepui (Gran Sabana, Venezuela).- Geomorphology, 106, 15-25.

Sauro, F., Piccini, L., Mecchia, M. \& J. De Waele, 2013: Comment on "Sandstone caves on Venezuelan tepuis: Return to pseudokarst?" by R. Aubrecht, T. Lánczos, M. Gregor, J. Schlögl, B. Smída, P. Liscák, Ch. Brewer-Carías, L. Vlcek, Geomorphology 132 (2011), 351-365.- Geomorphology, 197, 190-196.

Sauro, F., 2014: Structural and lithological guidance on speleogenesis in quartz-sandstone: Evidence of the arenisation process.- Geomorphology, 226, 106123.Striebel, T. \& V. Schaferjohann, 1997: Karstification of sandstone in Central Europe: Attempts to validate chemical solution by analyses of water and precipitates. Proceedings $12^{\text {th }}$ International Congress of Speleology, 10 ${ }^{\text {th }}-17^{\text {th }}$ August 1997, La Chaux des Fonts. Swiss Speleological Society, 473-476.

White, W.B., Jefferson, G. L. \& J.F. Haman, 1966: Quartzite karst in southeastern Venezuela.- International Journal of Speleology, 2, 309-314.

Wiegand, J., Fey, M., Haus, N. \& I. Karmann, 2004: Geochimische und hydrochemische untersuchungen zur genese von sandstein-und quarzitkarst in der Chapada Diamantina und im eisernen viereck (Brasilien).- Z. dt. Geol. Ges., 155, 61-90.

Wray, R.A.L., 1997a: A global review of solutional weathering froms on quartz sandstones.- Earth Sciences Reviews, 42, 137-160.Wray, R.A.L., 1997b: The formation and significance of coralline silica speleothems in the Sydney Basin, southeastern Australia.- Physical Geography, 18, 1-17.

Wray, R.A.L., 1999: Opal and chalcedony speleothems on quartz sandstone in the Sydney region, southeastern Australia.- Australian Journal of Earth Sciences, 46, 623-632.

Wray, R.A.L., 2013: Solutional weathering and karstic landscapes on quartz sandstones and quartzite.- In: Frumkin, A. (ed) Treatise on Geomorphology. Vol. 6. Karst Geomorphology. Elsevier, pp. 463-483, San Diego. 